\title{
Persona in spe. Anthropological and Theodical Aspects of Hope
}

\author{
Arkadiusz Gudaniec (D)
}

check for

updates

Citation: Gudaniec, Arkadiusz. 2021. Persona in spe. Anthropological and Theodical Aspects of Hope. Religions 12: 809. https://doi.org/10.3390/ rel12100809

Academic Editors: Piotr Roszak and Sasa Horvat

Received: 30 August 2021

Accepted: 22 September 2021

Published: 26 September 2021

Publisher's Note: MDPI stays neutral with regard to jurisdictional claims in published maps and institutional affiliations.

Copyright: (C) 2021 by the author. Licensee MDPI, Basel, Switzerland. This article is an open access article distributed under the terms and conditions of the Creative Commons Attribution (CC BY) license (https:/ / creativecommons.org/licenses/by/ $4.0 /)$.
Faculty of Philosophy, John Paul II Catholic University of Lublin, 20-950 Lublin, Poland; arkadiusz.gudaniec@kul.pl

\begin{abstract}
I intend to reflect on three phenomena that are revealed in the personal experience of hope: (1) hope distinguishes a person from the natural context, but it does so through nature, i.e., based on desires rooted in human nature; (2) hope is not only inscribed in the existential situation of human being, but also expresses the very meaning of human transcendence: the person transcends themself, because they live the hope of fulfillment in the transcendent reality; hope is a foretaste of a higher, more perfect life; (3) hope is a person's deeply experienced expectation of love, that is, of someone who loves. The above phenomena require a justification, which is the answer to the question "what is the reason for experiencing hope?". Carrying out analyses on the basis of the modernized metaphysics of the person, I refer primarily to the concept of personal acts, to the concept of religiosity as an essential property of the person and to elements of the concept of love. The conclusions of these analyses indicate the necessity of accepting the real existence of the object of human hope, since personal life essentially goes beyond contingency, towards wholeness in the form of union with Someone who loves.
\end{abstract}

Keywords: hope; person; human experience; classical conception of the person; personal transcendence; religiosity; love; nature; fulfilment; natural theology

One could say that man is alive as long as he waits, as long as hope is alive in his heart. And from his expectations man recognizes himself: our moral and spiritual "stature" can be measured by what we wait for, by what we hope for (Benedict XVI 2010)

\section{Introduction}

The sign of our times seems to be uncertainty, which humankind experiences on a global scale and which has been greatly exacerbated by the pandemic (Seryczyńska et al. 2021). Seemingly durable footholds, which have given people a sense of security, have collapsed. Questions about hope and meaning seem to echo ever more frequently and more clearly: Where are we heading, what is the meaning of our existence? Where can we find answers to the questions lingering in the depths of our existence? Where can we find hope, indispensable for living? In this somewhat dramatic situation that we find ourselves in, we also experience a crisis of authority. Science, to which humankind has largely entrusted its fate, has proved insufficiently effective and not reliable enough during this last ordeal. Therefore, perhaps the time has come to examine our personal experience with greater attention, which, as it seems, we can trust the most.

The subject of this paper is the phenomenon of hope, captured against the background of the entire elementary human experience. The main problem that has provoked this reflection is based on perceiving a clear structure of expectation in this experience: the state of being directed towards something. We live as though we were waiting for something and expecting something. Of course, we follow various specific goals that we set for ourselves or plan to achieve. However, looking a bit deeper, one can see some primary, basal expectation which always predates these goals, which, although undefined, is still present and accompanies us in the depths of our world experience, as well as in some acts of self-awareness. We discuss hope in its existential dimension, in which it presents itself as something highly unique and mysterious. Attention has been drawn thereto recently by 
philosophers like G. Marcel, E. Bloch, P. Ricoeur, and J. Pieper (Bloch 1986; Marcel 2010; Ricoeur 1970; Pieper 1986). Given the importance we place on the hope experienced in such a manner, we would probably place it among the deepest aspects of humanity, for it accompanies human beings throughout their lives, especially in extremely difficult or particularly significant times.

At this point, it will be necessary to adopt a few preliminary determinations of terminological and methodological nature. First, the anthropological character of this approach denotes examination of the original human experience, not an analysis of the concept of hope (on the method, see below). The principal interpretations placed on individual issues result from this kind of reflection. First, by placing personal experience at the centre of research, the basic plane of capturing the phenomenon of hope shifts from the sphere of the future, probably predominant in the conceptual discourse, to the sphere of the present, of current experience. In this way, through hope, we also become acquainted with its subject, the human being.

When talking about hope, I take into account the following aspects or elements: (1) expectation; (2) desire (strongly present: it is directed towards something, it "pushes" towards something); (3) longing (perceiving that something is desired, but unknown); (4) openness to (any) possibility of fulfilment; (5) readiness to endure hardships. Expectation seems to express the nature of hope the most, but this concept includes anxiety (in the face of the unknown), and hope-in a narrower sense, more in line with everyday experienceinvolves comfort and peace, a kind of certainty (with simultaneous lack of total certainty). Hope, which is very important, describes the existential state of human beings on their journeys, as if they were heading somewhere. In addition, it expresses a certain kind of acceptance and readiness for the hardships that this endeavour requires. This theme draws on classical philosophy, according to which the object of hope is the good which is difficult to obtain (Latin: bonum arduum) (ST I-II, q.40, a.1c). The very goal or object of endeavour, significant in theodical discourse, does not seem to be a direct element of hope, because, as I have mentioned, it is undefined with relation to content in the existential dimension. It is nonetheless an important assumption which will be extracted and analysed through reflection.

In the analyses conducted, three basic contexts of hope coexist: (1) the context of the elementary, everyday experience of hope (the aforementioned aspects perceived in human experience, regardless as to whether subjects experiencing it identify them with hope); (2) philosophical reading of the phenomenon of hope in human nature and personal experience; and (3) a theoretically constructed concept of hope, on the basis of a philosophically justified analogy: natural hope, present in all nature (I base this argument on the philosophical theory of analogy developed by M. A. Krapiec: Krapiec 1993b). These three contexts are closely interrelated: everyday experience reveals the foundations of hope in human nature, and human hope, in turn, is a special case of an inclination present in all nature. In addition to the above contexts, the theological context of hope ought to be mentioned, being often undertaken by thinkers, which in the present reflection-on account of its fundamentally philosophical nature-will not be taken into consideration by me (Lamb 2016).

My reflection will follow two paths, both of which intersect in various ways: (1) the experience of a person subjected to phenomenological analysis, and (2) elements of experience interpreted metaphysically, using arguments from classical philosophy, including the area of modernized metaphysics of the person. Here, I resort to the anthropological achievements of the Lublin Philosophical School, where studies were conducted on the harmonisation of classical approaches towards realistic metaphysics (Thomistic) with the phenomenological type of describing the person's original anthropological experience. The biggest steps in this regard were taken by K. Wojtyła, while M. A. Krapiec made the most significant contribution to the modernisation of classical metaphysics (Gudaniec 2020). I still consider this task as open and incredibly creative, and its greatest difficulty stems from the language, because the phenomenological description, focused on subjective experience, 
uses terminology different from the classical object-oriented language of metaphysics, applied to indicate the ontic reasons for phenomena given in experience. Achieving a sufficient level of harmonisation still seems to be an ideal difficult to attain. Moreover, it should be mentioned that one of the assumptions in this reflection is the thesis that such a philosophical analysis of personal experience is a source of rational knowledge (with an appropriate concept of rationality), ${ }^{1}$ just like empirical or scientific cognition. Only with such an assumption does a dialogue between science and philosophy become possible.

Reflection about a person and personal life plays a significant role in this text. The term "person" is understood here in line with the tradition of classical philosophy, where personhood is attributed to the human being by virtue of being a man or woman. Moreover, a person is the subject of a specific experience which does not allow that person to be reduced to a specimen of a species, described according to a purely natural model. On the other hand, the realism assumed at the starting point seems to be an adequate plane for discourse with naturalism.

The content presented below is integrated into a three-level basal structure: I. "nature" as a place where hope is born (points 2-3); II. "transcendence" as an experienced openness to a higher dimension of being (points 4-7); III. "love", which is a certain reading of the relation to this dimension (points 8-9). The last theme leads to the formulation of a particular hypothesis, based on a specific type of relationship between hope and love.

\section{Hope on the Foundation of Nature}

Nature seems to have been well studied by us, which is often the starting point for debates about the human being or a person. The concept of nature is certainly a subject for scientific discussions, but I do not intend to elaborate on this here; therefore, I shall limit myself to a simplified philosophical concept recognising nature as the source of determined action (PH 192b-193b). ${ }^{2}$ For the purposes of the following discourse, I interpret the operation of natural processes philosophically as the path from desire to fulfilment, with appropriate understanding of both terms. The concept of fulfilment requires a broader comment. It has its own objective and subjective dimension, the latter usually equated with happiness (which, among other things, clearly poses a cognitive problem: What is happiness?). In the objective aspect, considered here to be the primary one, it is a correlate of desire and is defined by it (in the context of nature). It is also important to distinguish between fulfilment which relates to a particular function or desire from one which relates to being as such. However, these two contexts are fundamentally related to each other: a being seeks to fulfil itself through the fulfilment (fullness, perfection) of its specific functions and actions. The fulfilment of a being presupposes its incompleteness, including some concept of contingency and potentiality: a being striving for fulfilment is not ready, but becomes so: i.e., it strives for its fullness. In anthropological discourse, the moral aspect of fulfilment seems to be quite significant: a person is fulfilled as either good or evil. This aspect would require a significant expansion of the research field, which is why in this reflection I shall essentially concentrate on the natural dimension of fulfilment reducing its role to the realisation of the desire present in nature.

What is embedded the deepest and, at the same time, present and marked in every truly human experience is desire, desiderium, which in turn underpins every endeavour. The dynamic side of human existence is most clearly visible in constantly experienced choices and dilemmas, linking our actions with appropriate objects and goals. This aspect is well reflected in the Latin word inclinatio-inclination towards something, being directed towards something. Inclinatio is a picture of the action of all nature, of every being: necessary, structural desires, inclinations, and then aspirations, transformations, actions aimed at achieving fulfilment, which is the purpose and sense of nature's existence, are commonly encountered in nature. It is a picture of the empirically available reality with which our human existence is intertwined.

It is essential for these considerations to draw attention to a certain elementary level of hope, which we can talk about at the level of nature. Every particle of nature derives 
the meaning of its existence from the "hope" that the natural inclination inherent in it will be fulfilled. For example, the function which a given element of nature must fulfil in the entirety of its existence (e.g., water, forests, air, rocks, etc.) may be considered to be such an inclination of nature. Here, hope is the expectation of fulfilment (of this function), connected with the force driving towards endeavour, the aim of which is to remedy some deficiency. This expectation is not only active, seeking fulfilment, demanding it, ${ }^{3}$ but it is also filled with a kind of certainty about fulfilment-since the strivings of nature are reliable.

Therefore, I use the term "hope" to describe natural phenomena which proceed in a determined manner. These phenomena are common and, moreover, show a significant similarity to the facts known from human experience; thus, hope can be assigned a certain universal meaning which allows it to be determined in various contexts by analogy. It is also important to remember the difference between hope, which denotes striving despite difficulties, and love or desire which strive to achieve a goal directly, without any consideration of the existence of obstacles. This difference derives from the classical tradition, which defined the object of hope as bonum arduum, a difficult good.

Natural desires are the driving force of life at every level. They set the directions and fields of action, aspirations, and development processes. By reflecting the cause of natural desires, we seek metaphysical explanations, which lead above all to the recognition of the existence of a privation, which is the principle explaining these phenomena. Without such a privation, there would be no endeavour to change, to attain a better state-as Aristotle used to say. The rational analysis of natural desire reveals its logical correlate, i.e., fulfilment. If in nature there exists a desire, being an expression of deficiency, its meaning is based on the real existence of the complement (filling, fulfilment). In other words: the logic of nature's functionality demonstrates that there would be no point in having any desire if it was not supposed to be finally satisfied. Such a desire would simply not be allowed to arise, as it would have to be contrary to a fundamental principle of nature. Natural desires are therefore an announcement of something new, which is to fill the privation present in the current state of nature.

At the level of nature, hope is most noticeable where life presents itself (Grassi 2020). A special hope related to the duration and fulfilment of life functions, despite all the hardships that nature poses in abundance, is embedded in a significant way in the very phenomenon of life itself. Hence, in the behaviour of animals and in the development processes of plants, numerous symptoms of expectation can be observed, conditioned by the need to develop and protect life, such as the hope of finding food, water, shelter, the possibility of escaping danger, etc. According to the scholastic tradition, hope (spes) is the first act of sensual irascible faculty (vis irascibilis), which is directed towards the difficult good. In the next stage of the activity of this faculty, another very important act thereof appears, namely courage. This plays an important role in ensuring the effectiveness of obtaining the good. Courage comes with struggle and sacrifice (ST I-II, q. 45, a. 1-3). Nature's path leading to the desired good, which is moreover difficult to obtain, is therefore not a passive expectation, but also includes struggle as a price worth paying to achieve fulfilment.

\section{Human Hope}

There is hope embedded in all nature that fulfilment will come despite the obstacles. It is an image of the positivity of life that can be read from the way nature works. The human being also has this natural positivity in themselves, as a syndrome of hope rooted in their nature-it spontaneously tends to seek fulfilment. The problem with hope begins on the cognitive side, in the face of arduous cognitive work and uncertainty, as well as in the face of freedom, which can either accept or reject this natural orientation (e.g., in the name of some idea of reason). However, hope itself as a natural force that leads to fulfilment, is indelible and manifests itself in various ways in human experience.

Human hope takes on a character different to a purely natural hope. This, of course, is related to the essentially different type of existence that human beings reveal in relation to 
other natural beings. They are, above all, aware of the actions of nature and can comprehend its essential aspects. Moreover, they determine their own actions by themselves, setting their own direction. In this way, all people form themselves through their conscious and free actions. Nevertheless, they have no knowledge of what fulfils them, having unsuccessfully sought their happiness in many objects and activities for centuries (Krapiec 1983, pp. 119-218, 351-59). Being by nature a recipient of cognitive curiosity to explore the essence of the world and its existence, they do not go beyond an endless set of unanswered questions, and almost every solution found raises further questions.

This is a certain paradox, perhaps most clearly noticeable nowadays: having achieved such a great deal of knowledge about the whole of nature and almost every part of it, humanity is still unable to fathom the mystery of its own existence, nor to explain the meaning of the existence of the world. Freedom of action, regarded as an essential property of the human species, does not reach perfection either, although we have been endowed with this quality by nature. Our numerous decisions are imperfect, revocable, constantly corrected, and made under the influence of various factors which determine them, preventing us from experiencing full freedom. In a similar respect, human love remains unsatisfied, seeking for complete happiness and unable to find rest for itself. This extraordinary power of bonding with anything that can fulfil us in some respects has also been received by us from nature.

Each of the listed activities, essential aspects of personal life, is an element of human nature, and therefore seeks fulfilment out of necessity. Through its own actions, by the power of natural desires and inclinations, every being strives to achieve a goal which is appropriate for it, by virtue of the irrefutable logic of the act of nature. Although the described personal actions are acts of nature, drawing their power from natural desires, they do not find fulfilment in nature. As in any other case, actions rooted in nature contain a guarantee of their fulfilment, the achievement of the purpose inscribed in the structure of a given action. We have called this guarantee and certainty "hope" in its elementary meaning. We can, therefore, formulate a thesis whereby hope, born in the realm of nature, does not lead to the fulfilment of actions essential for human beings, a fulfilment that would be available in nature. The path of hope in the human being does not reach its immanent end.

Consequently, we arrive at a fundamental observation: nature appears to be selfsufficient in all beings below the human level. The human manner of existence reveals its insufficiency: nature is unable to fulfil the desires that constitute the essence of human life. Being the birthplace of these desires, it cannot ensure their fulfilment—even though it assures such fulfilment to all other creatures of the natural world. Human beings do not find fulfilment in themselves, in their natural endowment, nor in their experiential interior, where their desires dwell. That is why they are a searching, unfulfilled, and even mysterious being, because compared to the whole "system" of nature's actions, the way in which they are to achieve fulfilment remains hidden and inaccessible.

\section{Hope Reveals the Person}

Nature establishes the necessary structures, and therefore human experience reveals something that cannot be removed, something irreducible that resists any attempt to deny, suppress or marginalize. The human being cannot resist searching for meaning, awaits answers, opens up to "something more", to something they do not know but desire. In the pursuit of fulfilment, they ultimately settle for nothing and feel that their desire cannot be satisfied. Therefore, there exists a certain primal structure in the human being, manifesting itself in the form of undying desire, which clearly grows stronger in the face of the threat of losing the meaning of life. This primal structure is expressed in the feeling of an urgent need for meaning, in the impossibility of living without a sense of meaning, or in a feeling of anxiety.

Is it not true that phenomena of this type-similar to the emotions and passions greatly valued and sometimes experienced by us, such as the admiration for all kinds of 
beauty — become more understandable when at their source we discern hope, revealing their orientation towards something that is unknown but desired? That is exactly what the content of these unique human experiences seems to be like: longing, nostalgia for something that attracts us so much, a foretaste of some more perfect, desired beauty. If this is the case, then we can conclude that hope lies at the root of the most sublime and intense human acts.

Continuing this thought, I shall use the following expression: in the realm of nature, the hope that comes to the human species, "reveals the person", i.e., a being that cannot attain fulfilment in nature. This is what we call transcendence or going beyond the level of nature. Hope, born of the desires of human nature, rises above nature and reveals a new perfection: the person. A person seeks fullness in their actions such as cognition, freedom, or love (Krapiec 1983, pp. 326-30). They seek perfect fulfilment in them, i.e., being oneself to the full. If these acts describe a person's transcendence in relation to nature the most accurately, it is precisely hope that seems to constitute the very heart of transcendence, as it best expresses its meaning. A person transcends their nature because, living in the hope of fulfilment, they turn towards something more. Hope therefore offers a foretaste of a better (more perfect) life, experienced in the most exalted personal acts and intense desires rooted in human nature. In hope understood in this way, one should therefore seek the foundations of the phenomenon of openness to the transcendent dimension, which is characteristic of human transcendence.

Revealing the person (through nature) manifests itself, first, in the fact of interiorisation of hope, i.e., making it internal, because hope-while simply indicating a reliable path to the fulfilment of desires in nature-is experienced in the human being, it constitutes an aspect of the experience of " $\mathrm{I}$ ". Such an interiorized phenomenon of hope takes the form of a more or less conscious expectation of fulfilment: a person lives in hope, experiences hope, that is, they relate to their desire and "strive" towards something more that could fulfil that desire. What a human being asks about, that is, the transcendent meaning of their life and existence, exceeds their abilities, and yet they carry these questions within themselves, thus discovering that they are a person. This is what proves that there is hope in this search, as otherwise such questions would not arise.

Second, revealing the person denotes the emergence of a new level, the level of the person, where nature finds no fulfilment in itself. Being a human being, as a specimen of a natural species, turns into being a person who, in the empirical explanation at our disposal in relation to nature, must ultimately remain a mystery. Based on natural desires, hope leads to an awareness of the meaning of life, or at least accompanies such awareness. It reveals the person, their dignity, and their uniqueness. The level of the person reveals a specific self-awareness and a free subject, shaping themselves from within, expressing themselves through their own autonomous acts.

However, "the person, then, not only is a consciousness, but has a nature," (Spaemann 2006, p. 103), i.e., they experience themselves simultaneously as a being belonging to the world of nature. Such nature-person opposition was investigated in the field of classical philosophy, with the adoption of a realistic concept of person and nature appropriate for this philosophy. The person is a being that transcends nature and adapts the natural aspects of their being to rational action, specific to a person. Persons exist in a unique way that allows them to respond to their nature. ${ }^{4}$ Hence the source of their action is something deeper than nature itself: "Because they are thinking beings, they cannot be categorized exhaustively as members of their species, only as individuals, who 'exist in their nature'" (Spaemann 2006, p. 33).

The specific actions of a person reveal something that has been called spirituality. The term is not necessarily considered here in reference to the resolutions of metaphysical nature, because certain aspects of this phenomenon are also, for example, the subject of phenomenological description. According to Wojtyła, thanks to the experience we obtain a positive sense of spirituality, not only its concept created through negating materiality (Wojtyła 1979a, pp. 47-48, 180). A person goes beyond their natural environment and 
reveals a mode of action that focuses on the reality as a whole, and not only on objects that satisfy the natural biological or psychological needs of the human being (Krapiec 1993a, pp. 602-7). The spiritual side of personal activities manifesting itself in this way is a clear indication of the transcendence of the person over nature. The priority of nature, despite its applicability to the entire cosmos, does not concern human activity because a human being is not a particularised nature in relation to the general idea of a species, but is a self-aware personal subject who "implements" humanity in themselves as their individual nature (Krapiec 1993a, p. 611). In the Middle Ages, during discussions concerning the Boethian definition of a person, it was emphasized that a person signifies a property that belongs to only one subject, an individual, and that the term itself is not a concept which denotes the general essence of a thing, but it is rather a generalized proper name (DT IV, c. 6; ST I, q. 30, a. 4c; Spaemann 2006, pp. 29-33). Hence a person is "somebody", rather than "something", which is only a concretization of a general essence. It stems from the fact that the person is not completely defined by their nature or "enclosed" within it. It should rather be concluded that the person possesses (although not fully) or implements their nature, and it is the core of their specific manner of existence (Spaemann 2006, p. 31; Wojtyła 1979a, pp. 83-85).

\section{The Promise of Fulfilment}

The topic of fulfilment, which stems from the idea of natural desire, at the level of human experience of hope, introduces a theme which can be described as the seed of fulfilment, or, if it is a part of a personal experience of desire, as the promise of fulfilment. In a sense, it represents the true heart of hope or the core of experiencing hope (living in hope). The structure in question is not a single unique moment in a person's experience, but rather it constitutes, as previously noted, its common and inerasable element, which is an ever-present background in personal experience. For in every truly personal act, in which a person expresses themselves in the fullest form, the seed of fulfilment is present, imparting meaning to these personal acts, including intellectual cognition, freedom, love, or creativity. In these actions a person searches for their own completeness, meaning and perfection of what they are. Therefore, it can be stated that the actual presence of such acts constitutes a certain guarantee of fulfilment, and the existence of hope has its foundation in strongly and clearly experienced natural desires.

Just as the whole of nature finds fulfilment, since a guarantee of satisfaction is contained in natural desire, the hope for the fulfilment of whatever nature reveals as the seed or promise is also a natural state for a person. From the perspective of personal experience, it can be stated, that nature, along with desire, gives a foretaste of completeness, and in this foretaste a person discovers the promise of fulfilment, and they seek to fully obtain what has been revealed as a foretaste, promise, or an announcement. All of these aspects are contained within hope, which is based on an unassailable principle, according to which nature must realize its striving, i.e., it must bring desire to fulfilment. The desires present in human nature must therefore reach fulfilment, i.e., personal acts in which human beings express themselves to the full must reach the state of fullness, "saturation", satiety. Otherwise, human beings would have to be considered absurd entities.

As noted by a Polish philosopher, who represented the Lublin School of Philosophy, M. A. Krapiec: over the course of a human life, the person "entangled" in the natural and material contexts of their own being does not encounter the full conditions needed to fulfil their most essential actions, which as actions that follow from human nature should be fulfilled:

Without the perspective of the fulfilment of personal-human acts (cognition, the desire of love), i.e., without the real as well as concrete possibility for every human being of the eternal endurance of that which already now has appeared in biological forms of duration as transcending matter, the very acts of cognition and love, if they were ultimately to succumb to change and time, would be yet another monster of nature, would be simply meaningless. (Krapiec 1983, p. 358) ${ }^{5}$ 
The manner of obtaining fulfilment by a person involves an activity specific to this person, which in some way reflects their own nature: this activity is rooted in materiality, but its ends go beyond the material realm. For personal activity is directed towards "enrichment of knowledge, the enrichment of love, the attainment of a higher degree of freedom in relation to all determinants" (Krapiec 1993a, p. 598). In conclusion, Krapiec states that:

These three actions—-knowledge, love, and freedom—completing each other, like the angles of a triangle, give the typical outline to how the person transcends nature and the 'nature of the world' that man has in himself through his body. (Krapiec 1993a, p. 616)

Through the phenomenon of the quest for fulfilment, in which the human being reaches outside the confines of nature, the personal dimension of hope is revealed as a basis for human desires and pursuits. The manner of extracting the person from nature through nature emerges in this manner. Thus, hope reveals a certain structural element of human existence, which consists in the passage from the natural level which somehow obscures the person, namely the level of humanity as a set of qualities essential for being human, to the level of a person "implementing" their human nature, i.e., to the point, when the unique, unrepeatable "I" of the person reveals itself. This can be described as a specific "birth" of the person, the emergence of the person from nature. However, as previously mentioned, this does not take place by means of opposing nature but results from the specific harmony between the person and nature.

This transition from nature towards the person draws attention to the understanding of human hope as a phenomenon which accompanies the human being throughout their entire lifetime, in every moment and in every action. For hope is the factor that imparts a meaning to all these acts and life as a whole, renders it something human, i.e., something proprietary, understandable, and heading towards a certain goal (Lysaker 2019). By virtue of this, human life acquires meaning, and therefore cannot be considered something absurd or trivial. Therefore, hope is a human act, which is present in a person's experience implicite, without realising its presence constantly as a road leading towards fulfilment-similar to the famous argument of St. Thomas, "while walking along the road one needs not to be thinking of the end at every step" (ST I-II, q. 1, a. 6, ad 3). In special cases, the act of hoping reveals itself explicite, e.g., when we ponder the meaning of life.

\section{Openness of the Person}

Primary experience seems to tell us, that without any expectations life loses its extraordinary and unique charm. When there is nothing to strive for or to expect, the horizon of life seems to inevitably undergo flattening and trivialization. Then, whatever is significantly human, whatever allows one to enjoy life and give it a relevant direction is missing. This means that hope is inscribed in the existential situation of the human being. The desire for fulfilment activates the search for completeness, which manifests itself in various personal activities.

Human hope contains "certainty" derived from nature, assuring us that fulfilment will come, but at the same time, unlike purely natural hope, it contains uncertainty-hence the tension and expectation-regarding when, how and by what means it will occur. For this reason, hope introduces an existential drama constituting an integral element accompanying almost every truly human experience. The same traits of human hope simultaneously reveal it as a gate open to the transcendent dimension. For hope not only exposes a person, but furthermore exposes their elementary openness. The openness to the unknown, reaching beyond the level of nature itself. Openness to "something more".

In a person's experience, the inclination to cross the boundaries of our cognition and willingness is clearly present, and its expression is an infinite range of objects falling into the scope of intellectual comprehension, as well as the infinite absorbability of will, seeking the satisfaction of the so-called desire for happiness. Hence, the openness in question denotes the openness of a person towards infinity, and thus the openness towards a higher 
dimension of life, since infinity is by no means a dimension of the natural world, or a manifestation of any available empirical experience, which is proven by negation contained in the linguistic construction of this term (Justo Domínguez 2019).

The human being is an entity of thorough openness, receptivity, an entity directed towards something and expecting something. As K. Wojtyła indicated, even human subjectivity is not a closed structure, as turning towards oneself proves to be a way of opening up to reality. For human beings realize themselves in their acts, through the transcendent dimension of their action, the principle of which is the truth of the good (Wojtyła 1979b, pp. 287-90). Openness is therefore a tendency of human nature, the elementary existential attitude of man, which is closely connected to hope. A specific manifestation of this tendency is the previously mentioned presentiment that there is "something more", since the person transcends themselves, i.e., their natural, empirically available dimension, because they live in hope of attaining fulfilment in some transcendent reality. This experience at a later stage can and should lead to the discovery of the object of hope, as the seed is the beginning, and the purpose of the beginning is fullness and completeness.

Here, it is worth considering a certain opposition being of significance for these considerations. Namely, natural hope, underlying the existential hope experienced by a person, is contrasted with the everyday hope present in the practical dimension, the meaning of which is summarized by the colloquial phrase "everything will be fine" (and, for this reason, it is often criticized, giving natural hope a bad name). While the former is embedded in human nature and is associated with an irresistible search for fulfilment, the latter, trivialized as a result of experiencing everyday worries, is devoid of a solid foundation and-as is well-known-often fails, unable to match the circumstances that contradict the vision of the future constructed by certain people. Nevertheless, the saying "everything will be fine" contains some truth about human hope, about the fact that there must exist some good that will ultimately prevail, survive, and save us (Kadlac 2017).

The status of hope as a companion of the human journey indicates that the meaning of human life is in the state of striving, becoming, searching, deciding, and wandering. The human being is essentially a bearer of hope (homo sperans), which "nourishes" them existentially. Hope is therefore a very particular trait of the human species. It describes the meaning of its personal existence: a being rooted in nature and leaning towards and leaning beyond, living and breathing expectation (Bovens 1999; Meirav 2009; Waterworth 2004). The revelation of hope uncovers the meaning of life to a person, adds gravity to life, makes it possible to discover, appreciate and save the deepest desires. It also fills everyday choices with energy, encourages existential questions, causes anxiety and dissatisfaction with meeting natural needs. What is our fulfilment then? What are we waiting for? Since meeting ad hoc needs turns out to be insufficient, what does it mean to be fulfilled, to achieve a full life?

\section{The Existence of the Object of Hope}

Openness to infinity, to a higher dimension of life, to transcendent reality is nothing other than religiosity in a neutral sense (i.e., one independent of religion), as a religious sense with which the human nature is endowed. Religiosity, appurtenant to the human being out of necessity, poses the question of the real foundation of being, the guarantor of the meaning of life, purpose, fulfilment, etc. This problem has been a challenge for humankind since time immemorial. If the inclination to ask questions about the ultimate meaning and the supernatural dimension of life dwells in human nature, there must also be an answer, justified in the realm of nature. The confirmation of the existence of the answer is somehow contained in the very fact that the question arises, if it is born of nature (i.e., it is necessary). Thus, the existence of an answer is ingrained in the very dynamics of the person, and in the structure of humanity. The very emergence of the question existentially arouses one to confirm the existence of the answer-even though the answer goes beyond the horizon of what can be empirically learnt. 
However, experiencing this existential tension in the normal course of life raises numerous problems. In this context, living in hope means enduring many hardships, which, in fact, is inscribed in its very essence. Mental difficulties cause certain complications. Lack of fulfilment, often acutely experienced, evokes, for example, feelings of anxiety, sadness, or loneliness. The extreme consequence of this type of experience is the attitude of rebellion and negation of life, namely, despair (Buss 2004). Based on the considerations so far, it can be argued that hope is more natural than despair as it is based on recognising the existence of the meaning of life, while despair, in a sense, implies that nature is false or absurd (ST I-II, q. 40, a. 4; II-II, q. 20, a. 1-4). Here, too, hope reveals its rationality. If we are rational beings, hope protects the meaning of our life; it is the ever-new willpower which enables us to continue our striving and positively experience the circumstances of life (Łukasiewicz 2021). Loss, pain, or suffering can be bearable as long as hope survives-and hope, objectively, is endless, because every person's life and existence is endowed with it.

In this context, it is worth discussing another psychological issue, which can be partially explained philosophically. The aforementioned existential tension and the related effort of "walking into the unknown" often lead to an attitude that can be called running away from oneself, namely, from taking one's own experience seriously. In practice, the anxiety related to the ever-imposing inevitability of human questions might be obscured by those created and consistently repeated habits, thanks to which one can forget (to some extent) about these questions and thus ignore the depth of one's own "self", which is expressed in hope. Running away from oneself, which is also an escape from reality, only worsens the situation, because when living in this way everything starts to seem alien, and life becomes burdensome and unbearable.

At the core of such thinking is, partly, the idea of modernity, with its characteristic claim to place the human subject at the centre- the "I" which was to have become the ruler of itself and all things. A further step is the idea of postmodernity leading to the arbitrary recognition of everything that evades human domination as an illusion or a game. Thereby, nowadays nihilism has become a very influential way of thinking and acting, turning out to be the main enemy of human hope.

The possibility of the existence of the unknown, the incomprehensible, as well as the possibility of an unpredictable event, is the culmination of human expectation, since a human being waits for a fulfilment whose timing and form is unknown. On the other hand, the contemporary person seems to say: "this is not possible" due to the cognitive difficulties they encounter. By denying the existence of an answer, they weaken the dynamism of the personal experience which leads to the answer through its natural power. If someone got lost in the forest and sensed a threat to their life, a cry for help would be the most reasonable option-but this cry implies the possibility that there is someone who will hear the calling. Otherwise, it would not make any sense (Carrón 2020, p. 25).

The assumption that an answer exists is therefore rational, hence the hope experienced by a person, based on their natural desires, is something deeply human, a real personal experience. Similarly, from the standpoint of personal hope, it is rational to maintain the assumption that something we cannot predict or understand may possibly exist or occur. However, taking a further step towards the content and object of hope, based mainly on rational and cognitive factors, is something not entirely evident, especially nowadays, and even, in view of the postmodern critique of cognition (Lyotard 1984; Sallis 1987), appears a bit suspicious.

The openness contained in hope is likewise infinite, because it exceeds all possible cognition (including imagination) of the object meeting the expectation. Therefore, if the object of hope exists (otherwise, hope itself would be futile), it is a mystery and an additional effort of the human spirit, an act of will, such as faith, is required to acknowledge it. However, due to the placement of faith in opposition to science in our times, the former seems to be a lost cause. Lack of trust in religious faith is one of the factors in the current crises related to the comprehension of the human condition, culture, and religion. 
In a sense, personal hope evades the above problem, as it allows people to experience human questions in the perspective of unlimited existential openness, thanks to which the ability to comprehend becomes a careful observation of reality, rather than a measure which is imposed upon it, when cognition is bereft of passion and saturated with suspicion. The fact that the human being is a rational being means that they open themselves (owing to hope) to what is unknown, incomprehensible, and what may become their fulfilment. The natural openness contained in hope, together with the longing for fulfilment experienced through its prism, becomes a factor which stimulates that side of personal experience which is responsible for communicating with reality, focusing attention on it, and bonding with it in various relationships. Therefore, while faith is by its nature oriented towards the cognitive activity of the subject, it may be assumed that hope triggers and penetrates its other side, which, according to the classical tradition, constitutes the domain broadly understood as love.

\section{A Person Is Fulfilled through a Person}

There is no doubt that the openness which is in some way carried by human hope also implies, in a significant sense, openness to other people, because the human being becomes especially fulfilled through interpersonal relations. This quality had already been noted by Aristotle, and the issue of a person's relationality has been extensively discussed in contemporary trends of thought about the human condition, together with so-called participation in a community of persons: the latter term was used by K. Wojtyła to define one of the factors essential for being a person (Wojtyła 1979a, pp. 261-99).

In the Aristotelian-Thomistic tradition, the uniqueness of relationships between persons was displayed, in which something, which may be called the revelation of a person, occurs. Against the background of the search for various goods that satisfy human needs, the other appears as something completely distinct from other objects of appetite (appetitus). The subject discovers a new category of good in it: "a good which is coveted for its own sake", a transcendent good, namely, one that goes beyond the concept of good according to the criteria of nature, where everything is desired merely to satisfy the subject. This new, higher reality of a person was referred to as "the virtuous good" (bonum honestum), because this good is worthy of being chosen to the highest degree. This can also be understood from the Aristotelian theory of friendship that, by discovering this unique good in another person and by binding to them with a special relation, which is true friendship, people may discover themselves and allow themselves to constantly explore their own rational and free nature. It is as if owing to a friendship they gained the right foundation for verifying the truth about themselves (NE 1166a, 1177b-1178a; Biss 2011). In this exact context there appears something that constitutes a clear breakthrough in the understanding of personal relations: the possibility of selfless love for another person (Rogers 1994).

St. Thomas Aquinas, while reflecting on the reasons for friendship and mutual love, recognized, i.a., that the good of the human individual refers by nature to the good of the whole, that is, a natural community, constituted by the nature of the human species (ST II-II, q. 26, a. 3; I, q. 60, a. 4-5; II-II, q. 47, a. 10, ad 2). ${ }^{6}$ Therefore, mutual love between people is something natural, and the closeness between people and the fact of forming friendships spontaneously is its trait:

Now, it is natural to all men to love each other. The mark of this is the fact that a man, by some natural prompting, comes to the aid of any man in need, even if he does not know him. For instance, he may call him back from the wrong road, help him up from a fall, and other actions like that: as if every man were naturally the familiar and friend of every man. (CG III, c. 117, 6)

Love for a person as the virtuous good, as Aquinas claims, perfects the very subject of love in the spiritual order. Self-fulfilment, which people strive for by virtue of a natural tendency called self-love (Greek: philautia), ${ }^{7}$ is achievable for a person to the highest degree by means of selfless devotion in love to another person (SE d. 29, a. 5). 
Based on the above, it may be concluded that persons fulfil themselves in a special way through another person: by seeking the fulfilment of their deepest desires in nature, they find a unique possibility in another, as a presentiment of their fulfilment. Thanks to this, human beings also gain the ability to overcome their own limitations, which, by enclosing themselves in themselves, prevent the realisation of their personal potential. For while human beings, because of these limitations, are rather inclined towards egoism, which does not lead to their fulfilment, selfless love turns out to be a force which directs them towards their actual fulfilment (Gudaniec 2015, pp. 195-204). The state of a person's perfection is therefore expressed in a selfless act of giving oneself to another person, which allows one to experience the uniqueness of the good as such, which, in the practice of human life, appears as a difficult and often incomprehensible good. ${ }^{8}$ Consequently, these themes fall within the scope of hope, the proper subject of which is the arduous good.

By virtue of personal existence, which is something most intimate and individual, untransferable and unique, the person was defined in classical philosophy as incommunicabilis-incommunicable. This expresses that unique quality of the person, thanks to which they have exclusive access to themselves and are "not transferred" outside themselves, and the limit of this non-transferability is freedom. Therefore, because of the experienced contingency and the resulting desire for fulfilment and being themselves more fully, people want to communicate to others this intimate part which they experience themselves. In this way, the essential incommunicability of the person becomes the basis of interpersonal communication, dialogue, interpersonal bonds, such as friendship, in which people unite to experience (in various aspects) their existence together and to be able to pursue improvement therein (Martinez 2006). The human race is called to this kind of community, as Aristotle seems to state, because only by creating such bonds are people able to help each other in the laborious pursuit of the ultimate purpose of their lives (PO 1253a; NE 1155a-b, 1171a-b).

In this existential drama of searching for the meaning of one's life and existence, people support each other by creating specific communities of hope. We are talking not only about psychological support, but also that which is inscribed in the very nature of hope: the other person "gives" hope, that is, calls to it, appears to be its image. The whole of mankind is also a great community of hope, a community of experiencing the human existential situation. The hope that unites all people becomes the basis of human solidarity, mutual respect, and kindness, for the sake of the desired good, which is something analogously common to all. The mutual love of human beings for one another, and the solidarity and compassion inspired by hope, as well as the foretaste of fulfilment in love, can be interpreted as the general human experience of the desire to be loved which lies at the heart of humanity. This factor, relevant for further analyses, is only mentioned here in the simplest possible formulation. Its existence and significant role seem to follow unquestionably from the arguments about love that have been considered so far.

\section{Love Is the End of Hope}

In accordance with a realistic concept of classical philosophy, which is to some extent verifiable in elementary personal experience, it is love-in opposition to cognition-which is associated with the object of love as it is in itself. This object is often insufficiently known, so love demands a constantly corrected and improved learning about it by abandoning one's own measures and discovering its truth. On the other hand, cognition, in accordance with its nature, takes its object in the form of a likeness, an image, adapting it to itself-that is, the inversion of what love does (ST I-II q. 22, a. 2; I-II q. 25, a. 2, ad 2; I-II q. 28, a. 1). The manner of uniting with what may lead a person to fulfilment, specific to human cognition, is therefore not able to guarantee this fulfilment, since it rejects the reality of the object, reducing it to its own scope (unless you rely on the supernatural refinement of cognition; ST III, q. 92, a. 1; Riplinger 2003).

Therefore, the certainty contained in personal hope is of a different kind than the certainty present in cognition, particularly in science. It is a certainty based on signs read 
from some person. A good example is a mother's love: the only evidence of this love is to be found in the signs that someone receives from their own mother-but these are not evidence in the scientific sense and could be questioned using strictly epistemological criteria. Nevertheless, we become certain of her love based on the signs received from her. Thus, since hope means waiting for something whose conditions of appearance are unknown, the main problem is not cognitive certainty, but attention to signs, i.e., vigilance and concentration. In other words, the lack of certainty in hope is not due to a lack of cognition, but to a lack of vigilance and amazement, the lack of some elementary positive feelings towards reality - that is, love.

As already mentioned, the transgression of nature present in the structure of hope signifies the transcendence of the human subject beyond the material order, towards a higher, personal order. The hope experienced in the depths of human experience not only becomes present in the form of a promise of fulfilment, but also becomes the basis of the premonition that the human being is directed towards something, as if called to something: as a person they are supposed to become somebody/something more. An invitation or a call read in this way reveals above all the personal character of this reference: the person invites or calls. On the other hand, an invitation or call is something that can be rejected, because, while questions about the meaning of life emerge from nature, they do not impose themselves in a mechanical and unfree manner. Therefore, a personal response, dialogue, a voluntary attitude of undertaking the path of the quest is necessary.

Hence, love is required from the person, both towards themselves and their existential questions that demand answers, as well as towards the reality which forms the fabric of life. Moreover, in relation to love towards others, we have read an essential property of the person, namely, relationality: people are dialogical beings, fulfilling themselves in the context of interpersonal relations. If the relations of love are experienced as a kind of foretaste of fulfilment, the mutual selfless dedication of friends is an expression of openness to the good which has the power of fulfilling the person. Therefore, it can be said that by sharing life, recognized by Aristotle as one of the main conditions of friendship (NE 1157b; Sherman 1987; Bryan 2009), a person discovers love for others, and this especially in giving oneself to them, as a way of participating in the expected fulfilment.

At this stage of revealing the content borne by the phenomenon of human hope, the relationship of the person to the transcendent dimension can already be read. As has already been suggested, this relationship does not take place at the level of cognition, since the final goal of life remains a mystery, but in the sphere of love: hope of fulfilment is de facto expectation of love. The hypothesis that I am formulating here seems to be a consequence of the arguments made so far. First, we have shown that the personal structure of hope is expressed in the elementary openness which results in attentiveness, vigilance, and concentration, being manifestations of love towards reality. Another aspect of this theme is the positivity of experiencing existence and sensing the existence of purpose, covered by the scope of human hope. Secondly, interpersonal relations have been shown as unique factors, providing a premonition of the possibility that fulfilment takes place through another person, and therefore by virtue of love, particularly selfless love. The fundamental element explaining the meaning of this type of relationship is the intensely experienced desire to be loved, affirmed, and accepted. The third theme is the dialoguepersonal dimension of hope, opening to the possibility of a personal bond as a fulfilment expected by nature.

Thus, this hypothesis concerning hope has two essential components. The first one is as follows: love is an adequate way of fulfilment, the picture of which is formed in the experience of hope. It is love that constitutes the expected fulfilment. Looking at the experience of a person through the prism of hope, we can see that each day of life is a kind of waiting for fulfilment, waiting for meaning and some desired fullness of life. At the end of the "journey of hope", the person is revealed as a being existing towards and destined for love, since they are a being fulfilled in love.

The second element of the hope hypothesis follows from the first one. Since the person is fulfilled in love, the end of the love relationship is also a person. Here, hope 
means opening up to the existence of the Person, ${ }^{9}$ who can ultimately bring human beings to fulfilment through love. They themselves, in relations of mutual love and friendship, experience a foretaste of this fulfilment, but each person continuously experiences their own deep desire, which imprints the stigma of insufficiency on the interpersonal bond. Hope opens human existence to personal love because it is a deeply experienced expectation of the Person with whom one can create a perfect community and engage in an intimate personal dialogue. At this point, we should also mention the connection between hope and desire for forgiveness, victory over evil and obtaining mercy, omitted in this reflection. This is a moral aspect of human fulfilment strongly present in personal experience which would deserve a separate study. This theme reveals even more clearly the personal face of the object of hope, since only a person can forgive, annihilate evil, and show mercy.

Therefore, human hope leads to love: full, personal, and ultimate. In conclusion, hope may be considered as a specific structure, rooted in nature and transcending it, the purpose of which is to prepare and introduce a person to love as a way leading to their fulfilment. Inside the human " $\mathrm{I}$ ", an urgent need for the ultimate meaning of life and existence is embedded, which is essentially the wait for a presence that will respond, save-preserve and fulfil-the human personal " $\mathrm{I}$ ", humanity. In this way, in the process of experiencing hope, the personal dimension of the One who calls and "gives" fulfilment (happiness) is revealed before the human being. If the human " $\mathrm{I}$ " is attentive, it can perceive in the depth of its hope this mysterious You, attainable through the relation of love.

In the light of all these considerations and above all in the light of the final statements, hope can be considered as a kind of cry, a prayer offered by nature to what gives meaning to nature, a supplication of the reason and feeling of the human being who does not want to live their life in vain. It is a request which permeates every human act, made by people who do not know (and may believe at best) who is the "You" they are waiting for.

\section{Final Conclusions}

This reflection was carried out concentrating on three basic aspects perceived through the prism of the personal experience of hope: (1) hope distinguishes a person from the natural context, but it does so through the mediation of nature, based on the desires rooted in human nature; (2) hope is not only inscribed in the existential situation of the human being but also expresses the very meaning of human transcendence: the person transcends themselves because they live in hope of fulfilment in a transcendent reality; hope provides the foretaste of a better (more perfect) life; (3) hope is a deeply experienced longing for love, that is, for someone who loves.

The synthesis of the path of hope can also be expressed in three theses: (1) natural desires demand fulfilment: hope, rooted in nature, cannot be pointless; (2) life strives for its fullness, that is, it goes beyond contingency: the essence of personal acts is to go beyond contingency in search of fulfilment, and therefore the object of human hope transcends nature; (3) the person is fulfilled through a person, which also means that the object of hope lies in the personal order; it is achieved in the manner of a love relation. In view of the difficulties related to the search for meaning and uncertainty, the cognitively lost human subject, so to speak, is "transferred" through hope to the level of love.

In connection with the final conclusion, a hypothesis was formulated, according to which hope is an introduction to the order of love, which is the dimension of a person's fulfilment (as an alternative to faith introducing one into to the transcendent cognitive order). Perhaps this aspect, with its more precise formulation and more detailed elaboration, will be able to constitute a new aspect to the debate on the purpose of a person's life, the possibility of human fulfilment, the search for meaning, etc. It should be emphasized that this statement does not denote a philosophical theory of happiness, in which love precedes cognition. This is more about showing the natural relationship between hope and love. Hope leads to love, while not excluding cognition or freedom. In these acts, a human being also experiences an anticipation of fulfilment, and moreover, as mentioned, they are fused with love into one personal experience. Speaking of the fundamental relationship between 
hope and love, I refer to a person's experience in the aspect of seeking fulfilment, which ultimately reveals itself as the Person: Someone who loves.

The phenomenon of hope calls for special justification. Its occurrence and the role it plays in personal experience causes us to face a serious dilemma: either there is a foundation of hope, and this phenomenon reveals a particular depth of the person, or we are forced to recognize the pointlessness of hope and thus the absurdity of personal experience at its core, in which personal transcendence is revealed. Absurdity would also mark the acts of a person, such as learning the truth for its own sake, admiration for beauty, selfless love, creativity, and finally religiosity, understood as openness to the transcendent dimension.

In the above analyses, two fundamental functions of hope were identified: (1) irresistible (because of its natural origin) striving for fulfilment-against obstacles which include various cognitive and existential difficulties (such as declines, doubts, suffering, etc.); (2) transgressing nature, i.e., transcendence, or revealing the person in the context of nature. The fundamental, individual experience of hope relates to the awareness that life is not an idyll and that there is still something to be fought for, to struggle with-but it has to be this way, it makes sense: hope gives meaning to life as if it were moving towards something. Depicting the pursuit of life fulfilment, hope imparts dignity to life, the maturity of experiencing often difficult circumstances. Hope says a lot about a person without saying anything specific. It is an open gate to something unknown, towards which all seem to be headed by the power of hope.

Perhaps this reflection has shown that in the current debate on the human being, the meaning of their life and the meaning of the world in which they live, the probably indispensable voice of philosophy is also required, especially the one that respects the seriousness of existential, human questions the most. Philosophical discourse may oppose naturalistic reduction, which is, in fact, a loss of faith in another dimension of human existence which eludes the methods of modern natural sciences. Naturalism is not capable of recognising the uniqueness of the human being but aims to prove their complete unity with the nature of the cosmos, perceiving the human being's existence as enclosed in temporality.

Who shall we be when we have been deprived of hope? Is it possible to be a person without hope? These questions provoke reflection on the role of hope in human life. It can be captured in a diagram showing the opposition between a person of hope and a person who rejects hope (a human being without hope). Whereas the former feels longing, doubts run through the mind of the latter. The former engages in the search, while the latter forces negation, the rejection of the existence of an answer. As a result, whereas the former is characterized by elementary openness, a readiness to accept the existence of what is unpredictable, the latter expresses the opposite, claiming "I already know". Hope, experienced in connection with the search for fulfilment, the meaning of life, gives the human being a sense of dignity, stimulates compassion, brotherhood, and solidarity with others. When hope and its activating force are missing, human life loses its personal dimension and often collapses, without the necessary support in the form of a guarantee of the purpose and strength to endure existential hardships.

The personal context of hope, according to how it is experienced and how it reveals the person, is not distant from the theological meaning of hope, related to the Christian context, which places hope in the middle of the great triad of supernatural virtues: faithhope-love. Faith and love can be interpreted in a way analogous to the one in which we analysed hope from the perspective of nature (the latter has been sufficiently studied, as I have already mentioned). Faith would concern the question of the existence of the ultimate goal of life-hope: the path that leads to the goal, along with the hypothetically expressed intuition pertaining to the nature of this goal, which is the Person-while love, focused entirely on the personal order, would concern the union with that goal-Person. Thereby, it would be possible to philosophically map out the natural roots of the theological virtues which constitute the essential elements of natural theology. 
The reflections presented here essentially exhibit the existential roots of hope, to the extent that philosophy can make them clearer, as a basis of what was perfectly incorporated into the theory that recognizes hope as a theological virtue, which appears to take into account the nature of the person to a considerable degree (Schoot et al. 2015; Milona 2020). Undertaking a reflection of philosophical nature, it is possible to demonstrate the road leading from existential hope to "sanctified hope", from nature to grace. In a sense, hope harmonizes those two orders, the order of nature and the order of grace, at the level of experience. To discover the order of grace and its existential dimension, one needs to walk the path from the beginning, that is, from nature, from what is obvious and basic, asking about the meaning, about what is final.

The above reflection constitutes a proposition for a specific way of viewing the phenomenon of human hope, as well as addressing certain significant elements thereof, at the same time provoking subsequent, perhaps more detailed and comprehensive analyses. My intention was to draw attention to the fundamental importance of hope in experience, and to reveal to a greater extent through this what constitutes the uniqueness of the person, which still remains relatively insufficiently investigated.

Funding: This project has been funded by the Minister of Science and Higher Education within the program under the name "Regional Initiative of Excellence" in 2019-2022, project number: 028/RID/2018/19, the amount of funding: 11742500 PLN.

Conflicts of Interest: The author declares no conflict of interest.

\section{Abbreviations}

CG Thomas Aquinas, Contra Gentiles. On the Truth of the Catholic Faith. Translated by Vernon J. Bourke. Edited, with English, especially Scriptural references, updated by Joseph Kenny O.P. New York: Hanover House, 1955-1957. Available online:

https:/ /isidore.co/aquinas/english/ContraGentiles.htm (accessed on 1 August 2021).

DT Richard of St. Victor, De trinitate, in: J. P. Migne, Patrologiae cursus completes. Latina series, vol. 196. Paris: Garnier Fratres, 1880. Digitized copy Available online:

https: / www.scribd.com/document/59437361/Migne-Patrologiae-cursuscompletus-Series-latina-1800-Volume-196 (accessed on 1 August 2021).

NE Aristotle. Nicomachean Ethics. In Aristotle in 23 Volumes, vol. 19. Translated by H. Rackham. Cambridge, Mass.: Harvard University Press; London: William Heinemann Ltd., 1934.

PH Aristotle. Physics, Books I-IV. In Aristotle in 23 Volumes, vol. 4. Translated by P. H. Wicksteed, F. M. Cornford. Cambridge, Mass.: Harvard University Press; London: William Heinemann Ltd., 1929.

PO Aristotle. Politics. In Aristotle in 23 Volumes, vol. 21. Translated by H. Rackham. Cambridge, Mass.: Harvard University Press; London: William Heinemann Ltd., 1932. Thomas Aquinas, Scriptum super III librum Sententiarum. In Sancti Thomae de Aquino Opera Omnia, recognovit et instruxit E. Alarcón automato electronico Pompaelone ad Universitatis Studiorum Navarrensis aedes a MM A.D. Available online at: https:/ / www.corpusthomisticum.org/iopera.html (accessed on 1 August 2021). Thomas Aquinas, The Summa Theologiae. Literally translated by Fathers of the English Dominican Province. Second and Revised Edition, 1920. Available online: https:/ / www.newadvent.org/summa/1076.htm (accessed on 1 August 2021).

\section{Notes}

1 In anthropological reflection, describing and explaining the primary human experience, we repeatedly enter the field of individual experiences (so called first-person experiences), which cannot be captured using empirical methodology, but it is possible to interpret them using philosophical tools.

2 This type of understanding of nature, which in fact constitutes the common heritage of science in the broad sense, is derived from Aristotle's concept. A distinction is also made between nature as the natural world and the nature of things, which primarily concerns the essence of things in terms of the principle of action. 
3 This aspect of struggle and inclination is reflected in the Latin name of appetitive power: appetitus, which contains demanding and requesting-ad-petere. It is used as a term for the whole structure present in living beings, which directs them towards achieving appropriate objectives.

4 St. Thomas Aquinas believed that a person is an existence proper and proportional for a given nature: "Ipsum esse est personae subsistentis, secundum quod habet habitudinem ad talem naturam" (ST III, q. 17, a. 2, ad 4); or elsewhere: "Nam esse pertinet ad ipsam constitutionem personae, et sic quantum ad hoc se habet in ratione termini. Et ideo unitas personae requirit unitatem ipsius esse completi et personalis" (ST III, q. 19, a. 1, ad 4).

5 The answer to this obstacle in understanding human nature is Krapiec's concept (hypothesis) of personal death comprehended actively (Krapiec 1983, pp. 335-62).

$6 \quad$ Elsewhere Aquinas says: "For there should be a union in affection among those for whom there is one common end. Now, men share in common the one ultimate end which is happiness, to which they are divinely ordered. So, men should be united with each other by a mutual love. Again, whoever loves a person must, as a consequence, also love those loved by that person and those related to him. [ ... ] Besides, since 'man is naturally a social animal,' he needs to be helped by other men in order to attain his own end. This is most fittingly accomplished by mutual love which obtains among men" (CG III, c. 117, 2-4).

7 According to Aristotle, self-love is an expression of the potential nature of the human being, out of necessity striving to realise the capabilities contained in them (NE 1166a, 1168a-1169a; Annas 1989).

8 In Thomistic metaphysics the good as such (Latin: bonum simpliciter) is the proper object of the will as the power of wanting. This good reveals itself especially as a good which is wanted for its own sake. The subject of selfless love in Aquinas's philosophy is discussed in Gudaniec (2015).

9 I intentionally do not introduce the term "God" here, although this is also a paper on theodicy. By using a capital letter in "Person", I de facto assume this theme, but thanks to this I do not leave the realm of personalistic considerations.

\section{References}

Annas, Julia. 1989. Self-love in Aristotle. Southern Journal of Philosophy 27: 1-18. [CrossRef]

Benedict XVI. 2010. Angelus 28 November 2010. Available online: https:/ / www.vatican.va/content/benedict-xvi/en/angelus/2010 /documents/hf_ben-xvi_ang_20101128.html (accessed on 1 August 2021).

Biss, Mavis. 2011. Aristotle on Friendship and Self-knowledge: The Friend beyond the Mirror. History of Philosophy Quarterly 28: 125-40.

Bloch, Ernst. 1986. The Principle of Hope. Translated by Neville Plaice, Stephen Plaice, and Paul Knight. Cambridge: The MIT Press, vols $1-3$.

Bovens, Luc. 1999. The Value of Hope. Philosophy and Phenomenological Research 59: 667-81. [CrossRef]

Bryan, Bradley. 2009. Approaching Others: Aristotle on Friendship's Possibility. Political Theory 37: 754-79. [CrossRef]

Buss, Sarah. 2004. The Irrationality of Unhappiness and the Paradox of Despair. The Journal of Philosophy 101: 167-96. [CrossRef]

Carrón, Julián. 2020. The Radiance in your Eyes. What Saves us from Nothingness? Translated by Sheila Beatty. Odessa: Human Adventure Books, Available online: https:/ /it.clonline.org/cm-files/2020/08/05/jc-brillio-web-ing.pdf (accessed on 1 August 2021).

Grassi, Martin. 2020. Self-organized bodies, between Politics and Biology. A political reading of Aristotle's concepts of Soul and Pneuma. Scientia et Fides 8: 123-39. [CrossRef]

Gudaniec, Arkadiusz. 2015. Paradoks bezinteresownej miłości. Studium z antropologii filozoficznej na podstawie tekstów św. Tomasza z Akwinu. Lublin: PTTA-KUL.

Gudaniec, Arkadiusz. 2020. Metaphysics of the Person: The Specificity of Personalism in the Lublin Philosophical School. In The Lublin Philosophical School. History-Conceptions-Disputes. Edited by Agnieszka Lekka-Kowalik and Paweł Gondek. Lublin: KUL, pp. 121-41.

Justo Domínguez, Emilio J. 2019. Immortal Life and Eternity. On the Transhumanist Project of Immortality. Scientia et Fides 7: $233-46$. [CrossRef]

Kadlac, Adam. 2017. Hope(s) and Hopefulness. American Philosophical Quarterly 54: 209-21.

Krapiec, Mieczysław A. 1983. I-Man. An Outline of Philosophical Anthropology. Translated by Marie Lescoe, Andrew Woznicki, Theresa Sandok, and et al.. New Britain: Mariel Publications.

Krapiec, Mieczysław A. 1993a. Odzyskać Świat Realny. Lublin: TN KUL.

Krapiec, Mieczysław A. 1993b. Teoria Analogii Bytu, 2nd revised ed. Lublin: RW KUL.

Lamb, Michael. 2016. Aquinas and the Virtues of Hope: Theological and Democratic. Journal of Religious Ethics 44: 300-32. [CrossRef]

Łukasiewicz, Elżbieta. 2021. Why Hope Cannot Be an Intellectual Virtue: Rationality of Hope Considered from an Analytic Perspective. Roczniki Filozoficzne 69: 5-38. [CrossRef]

Lyotard, Jean-François. 1984. The Postmodern Condition: A Report on Knowledge. Translated by Geoff Bennington, and Brian Massumi. Minneapolis: University of Minnesota Press.

Lysaker, John T. 2019. Looking After the Future: Notes on Hope. The Journal of Speculative Philosophy 33: 238-55. [CrossRef]

Marcel, Gabriel. 2010. Homo Viator. Introduction to the Metaphysics of Hope. Translated by Emma Craufurd, and Paul Seaton. South Bend: St. Augustine's Press. 
Martinez, Enrique. 2006. Vida personal y comunicación interpersonal. Consideraciones sobre la metafísica de la persona en Santo Tomás de Aquino. Revista Española de Filosofía Medieval 13: 81-8. Available online: https://www.academia.edu/8470823/ PERSONAL_LIFE_AND_INTERPERSONAL_COMMUNICATION (accessed on 1 August 2021).

Meirav, Ariel. 2009. The Nature of Hope. Ratio 22: 216-33. [CrossRef]

Milona, Michael. 2020. Discovering the virtue of hope. European Journal of Philosophy 28: 740-54. [CrossRef]

Pieper, Josef. 1986. On Hope. Translated by Mary Frances McCarthy. San Francisco: Ignatius Press.

Ricoeur, Paul. 1970. Hope and the Structure of Philosophical Systems. Proceedings of the American Catholic Philosophical Association 44: 55-69. [CrossRef]

Riplinger, Thomas. 2003. The Psychology of Natural and Supernatural Knowledge according to St. Thomas Aquinas. Tübingen: Universität Tübingen, Available online: https://publikationen.uni-tuebingen.de/xmlui/bitstream/handle/10900/43975/pdf/ ThePsychology-complete.pdf?sequence=1\&isAllowed=y (accessed on 1 August 2021).

Rogers, Kelly. 1994. Aristotle on Loving Another for His Own Sake. Phronesis 39: 291-302. [CrossRef]

Sallis, John, ed. 1987. Deconstruction and Philosophy: The Texts of Jacques Derrida. Chicago: University of Chicago Press.

Schoot, Henk, Harm Goris, and Lambert Hendriks, eds. 2015. Faith, Hope and Love: Thomas Aquinas on Living by the Theological Virtues. Leuven: Peeters Publishers.

Seryczyńska, Berenika, Lluis Oviedo, Piotr Roszak, Suvi Saarelainen, Josefa Torralba Albaladejo, Francis-Vincent Anthony, and Hilla Inkilä. 2021. Religious capital as a central factor in coping with the Covid-19: Clues from an international survey. European Journal of Science and Theology 17: 67-81.

Sherman, Nancy. 1987. Aristotle on Friendship and the Shared Life. Philosophy and Phenomenological Research 47: 589-613. [CrossRef] Spaemann, Robert. 2006. Persons. The Difference between 'Someone' and 'Something'. Translated by Oliver O'Donovan. Oxford: Oxford University Press.

Waterworth, Jayne M. 2004. A Philosophical Analysis of Hope. Basingstoke: Palgrave Macmillan.

Wojtyła, Karol. 1979a. The Acting Person. Translated by Andrzej Potocki. Dordrecht: Reidel.

Wojtyła, Karol. 1979b. The Person: Subject and Community. The Review of Metaphysics 33: 273-308. 